IRSH 58 (20I3), Special Issue, pp. I 3 I-I I I doi:I0.I0I7/S00208590I300029I (C) 2013 Internationaal Instituut voor Sociale Geschiedenis

\title{
Anti-Impressment Riots and the Origins of the Age of Revolution*
}

\author{
Christopher P. MA GR A \\ Department of History, University of Tennessee \\ 9Is Volunteer Blvd, Knoxville, TN 37996-4065, USA \\ E-mail: cmagra@utk.edu
}

\begin{abstract}
This essay details the relationship between anti-impressment collective actions, the American Revolution, and the age of revolution. Naval impressment represented the forcible coercion of laborers into extended periods of military service. Workers in North American coastal communities militantly, even violently, resisted British naval impressment. A combination of Leveller-inspired ideals and practical experience encouraged this resistance. In turn, resistance from below inspired colonial elites to resist British authority by contributing to the elaboration of a political discourse on legitimate authority, liberty, and freedom. Maritime laborers stood on the front lines in the struggle for freedom, and their radical collective actions helped give meaning to wider struggles around the Atlantic world.
\end{abstract}

Seafarers William Conner, Michael Corbet, Pierce Fenning, and John Ryan were Irish Americans living and working in Marblehead, Massachusetts, the foremost fishing port in British North America. On 22 April 1769, they were homeward bound from Cadiz, Spain on board the Pitt Packet, a brig that belonged to Robert "King" Hooper, a wealthy fish merchant in Marblehead, with a load of salt to be used in the colonial fisheries. Benjamin Caldwell, captain of HMS Rose, was stationed outside Marblehead's harbor. Caldwell ordered the Pitt Packet to strike sail and await inspection. He then sent Lieutenant Henry Gibson Panton with several armed seamen to board the Pitt Packet to force men into naval service, a practice known as impressment. The Irish-American workers locked themselves in the brig's hold. Panton ordered the door to the hold

\footnotetext{
* The author would like to thank all of the participants at the 20I I Maritime Radicalism conference and the members of the 2012 Maritime Radicalism workshop for their constructive feedback on early drafts of this essay. Funding from the Department of History, University of Tennessee, and the International Institute of Social History in Amsterdam, the Netherlands, made travel to these meetings possible.
} 
to be broken down, and the press gang rushed in. Conner, Corbet, Fenning, and Ryan stood amidst piles of salt armed with fishing implements, ready to defend themselves. A tense standoff ensued. Corbet grabbed a harpoon and a handful of salt. He threw a line of salt before the press gang and swore that any man that crossed it would die. Panton stepped over the line. Corbet launched his harpoon at the Lieutenant, hit him in the neck, and severed his jugular. While some of the press gang attacked the Marblehead mariners, others carried Panton up to the main deck, where he bled to death. After a short fight, the gang overwhelmed and arrested the Irish Americans, who were arrested and tried for murder in a specially convened Vice Admiralty court in Boston, Massachusetts. ${ }^{\text {I }}$

On the other side of the Atlantic, impressed sailors were organizing a mutiny on their way to the Nore in March I77I. The Royal Navy was mobilizing for what was presumed to be another war with France. A press gang at Newcastle had captured I 60 maritime laborers. These pressed men were being transported by sea to HMS Conquestador at the Nore. John Falkingham, captain of the Conquestador, reported that he only "received 85 men". The remaining 75 pressed men, along with 2 volunteers, had "risen against the crew" of the transport vessel, "the Active tender", en route to the Nore. The savvy mutineers "destroyed the lists which were sent by Captain Bover [the regulating captain in charge of the Newcastle press gang]". These lists recorded names and places of residence. After seizing control of the vessel, the mutineers "obliged the [Active's] pilot to carry her into the Port of Whitby; by which means, seventy seven Impressed men and Volunteers made their Escape". ${ }^{2}$ Separated by an ocean, workers whose lives revolved around the sea resisted the Royal Navy and thereby helped to usher in the age of revolution.

Historians have now studied the radical dimensions of the age of revolution for over fifty years, but the maritime nature of radical ideas and actions has for the most part been neglected. ${ }^{3}$ When anti-impressment

I. L. Kinvin Wroth and Hiller B. Zobel (eds), Legal Papers of John Adams, 3 vols (Cambridge, MA, 1965), II, pp. 275-335. For coverage in the Boston Evening Post, the New York Journal, and the Pennsylvania Chronicle, see Oliver Morton Dickerson (comp.), Boston Under Military Rule, I768-I769, As Revealed In A Journal of the Times (Westport, CT, 1971), pp. 94-95, I04-105.

2. The National Archives, Kew, UK (TNA), Records of the Navy Board and the Board of Admiralty (ADM), 106/1 197/239.

3. Recent work on the radicalism of the age of revolutions includes Alfred F. Young, Gary B. Nash, and Ray Raphael (eds), Revolutionary Founders: Rebels, Radicals, and Reformers in the Making of the Nation (New York, 20I I); David Andress, The French Revolution and the People (London, 2006); Gary B. Nash, The Unknown American Revolution: The Unruly Birth of Democracy and the Struggle to Create America (New York, 2005); and Sibylle Fischer, Modernity Disavowed: Haiti and the Cultures of Slavery in the Age of Revolution (Durham, NC, 2004). An exception to the neglect of maritime radicalism is Peter Linebaugh and Marcus 
collective actions are discussed in relation to the American Revolution that opened the age of revolution, they are commonly portrayed as apolitical affairs in which angry workers on the margins of mainstream society simply wanted to avoid unwholesome military service and familial separation. ${ }^{4}$ Only a few historians have maintained that maritime laborers had a political consciousness and acted on it. This consciousness has been described as "liberal", in the modern sense of the term, as workers were willing to wait for change to occur.' Peter Linebaugh and Marcus Rediker stand apart in their insistence that the workers engaged in eighteenthcentury anti-impressment riots were motivated by radical ideas.

Their work highlights the ways in which ideas about egalitarianism and freedom circulated around the Atlantic world during the long and uneven transition to capitalism. Such ideas, combined with a shared experience with capitalist expropriation and exploitation, linked merchant mariners, pirates, slaves, and even those involved in anti-impressment collective actions into one transatlantic, many-headed proletariat that resisted Herculean efforts on the part of a ruling class to keep workers in check. ${ }^{6}$

This essay presents a sea-centered portrait of the radical ideology and behavior associated with anti-impressment collective actions in colonial America on the eve of the American Revolution. These actions were public, and therefore relatively well-recorded, illuminating the ways in which maritime radicalism (radical ideas and behavior directly related to life at sea) influenced the revolutionary movement that brought about an independent United States of America and ushered in the age of revolution. ${ }^{7}$ Life and work at sea was central to radical actions and beliefs

Rediker, The Many-Headed Hydra: Sailors, Slaves, Commoners, and the Hidden History of the Revolutionary Atlantic (Boston, MA, 2000).

4. See, for example, Denver Brunsman, "Subjects vs Citizens: Impressment and Identity in the Anglo-American Atlantic", Journal of the Early Republic, 30 (2010), pp. 557-586; Keith Mercer, "Northern Exposure: Resistance to Naval Impressment in British North America, I775-I 8 I 5 ", Canadian Historical Review, 9I (2010), pp. 199-232; Nicholas Rogers, The Press Gang: Naval Impressment and its Opponents in Georgian Britain (London [etc.], 2007); Paul A. Gilje, Liberty on the Waterfront: American Maritime Culture in the Age of Revolution (Philadelphia, PA, 2004); N.A.M. Rodger, The Wooden World: An Anatomy of the Georgian Navy (London, 1986); and Pauline Maier, From Resistance to Revolution: Colonial Radicals and the Development of American Opposition to Britain, 1765-1776 (New York, 1972).

5 . Jesse Lemisch maintains that colonial maritime laborers who resisted impressment were "liberal" not "radical". Workers wanted change. They demanded that the very old use of state power to appropriate labor come to an end. The crucial point for Lemisch, however, is that the colonial maritime laborers that rioted against British naval impressment were "patient" and they were "not willing to destroy the present system to achieve a better one". See Jesse Lemisch, Jack Tar vs John Bull: The Role of New York's Seamen in Precipitating the Revolution (New York, I997), p. xix.

6. Linebaugh and Rediker, The Many-Headed Hydra.

7. The term "radical" in this essay refers to actions that contemporaries perceived as being subversive, or potentially subversive, to the existing order of things. Christopher Hill, an expert 
from below that helped push colonial elites, the so-called Founding Fathers, into armed rebellion against the British Empire. Maritime laborers' radicalism inspired both fear and conviction in elites that the world might be turned upside down.

Sea power provided the means for the expansion of the British Empire across the Atlantic world. In waters teeming with pirates, privateers, and enemy warships, a strong navy made it possible for commerce, communication, and conquest to extend out from Albion's island shores over the course of the I600s and I700s. In the words of John Evelyn, an English writer and a commissioner in charge of tending to wounded seamen during the Second Anglo-Dutch War,

To pretend to Universal Monarchy without Fleets was long since looked upon as a politic[al] chimera [...] whoever commands the ocean, commands the trade of the world, and whoever commands the trade of the world, commands the riches of the world, and whoever is master of that, commands the world itself. ${ }^{8}$

British naval expansion could not have occurred without the coercion of maritime labor. There has long been a consensus among historians of the early modern British navy that impressment was integral to manning efforts. ${ }^{9}$ Nicholas Rogers has made the most concerted effort to quantify impressment. He concludes that of the 450,000 men who served in the British navy between I740 and I 8 I 5 , 40 per cent were pressed. ${ }^{\circ}{ }^{\circ}$ In other words, nearly half of Britain's combat strength was coerced into military service over this 75 -year period.

Eighteenth-century eyewitnesses also saw impressment as vital to manning the British fleet. John Nicol, a common Scottish tar who served

on early modern radicalism, wrote that radical ideas such as Gerard Winstanley's mid-seventeenth-century call to put the poor first, represented a "subversion of the existing social order". See Christopher Hill, The World Turned Upside Down: Radical Ideas during the English Revolution, (4th edn, New York, I99I), p. 38. By collective resistance, I refer to group behavior based on mutual understanding and assent, as opposed to individual action predicated solely upon self-interested motives not shared by others.

8. John Evelyn, Navigation and Commerce, Their Origin and Progress (London, 1674), pp. I $5-17,32-33$.

9. Denver Brunsman, "Men of War: British Sailors and the Impressment Paradox", Journal of Early Modern History, I 4 (2010), pp. 9-44; Mercer, "Northern Exposure"; Rogers, Press Gang; Stephen F. Gradish, The Manning of the British Navy During The Seven Years' War (London, 1980); Daniel A. Baugh, British Naval Administration in the Age of Walpole (Trenton, NJ, 1965); Neil R. Stout, "Manning the Royal Navy in North America, 1763-1775", American Neptune, 23 (1963), pp. I74-185; Richard Pares, "The Manning of the Navy in the West Indies, 1702-63", Transactions of the Royal Historical Society, 20 (1937), pp. 31-60; and John Robert Hutchinson, The Press-Gang Afloat and Ashore (London, I9I3). N.A.M. Rodger stands apart from this consensus. In an investigation of the muster books of five random warships from the Seven Years' War, he concludes that only is per cent of the men had been pressed; Rodger, The Wooden World, app. III.

Io. Rogers, Press Gang, pp. 5, 40. 
in the Royal Navy in I776, observed "I was surprised to see so few who, like myself, had chosen [naval service] for the love of that line of life. Some had been forced into it by their own irregular conduct but the greater number were impressed men". "In I775, at the start of the American Revolution, Vice Admiral Samuel Graves, commander of the British North American squadron stationed off Massachusetts, reported in a letter to Philip Stephens, Secretary of the Admiralty Board, that "Necessity obliges me, contrary to my inclination, to use this method to man the King's Ships". ${ }^{\text {2 }}$ Judge Serjeant Foster adjudicated a very important legal case in 1743 in which a mariner killed a naval officer while resisting impressment. Foster famously ruled against the mariner and defended the institution of impressment. In his ruling, Foster stated:

This Question touching the Legality of Pressing Mariners for the Public Service is a Point of very great and National Importance [...]. As to the Point of Public Safety, it would be time very ill spent for me to go about to prove that this Nation can Never be Long in a State of Safety, Our Coast defended and our Trade protected, without a Naval Force Equal to All the Emergencies that may happen. And how can We be Secure of such a Force? [...] I do not know that the Wisdom of the Nation has hitherto found out any Method of Manning our Navy, less inconvenient than Pressing; And at the same time Equally sure and Effectual. ${ }^{13}$

The British navy could not have safeguarded shipping lanes and maintained key Atlantic stations over the course of the eighteenth century without impressment. Without the ability to regularly patrol key strategic points in the Atlantic world, transatlantic shipping would have been put at greater risk. Increased risk meant higher maritime insurance rates for shippers, and it meant a reduction in the degree of predictability that was a key component of the free flow of goods. In short, without a sufficiently manned navy, Britain's maritime empire would have been vulnerable.

Like mutiny, resisting impressment was highly subversive in the context of the eighteenth-century British Atlantic world. A 1759 Act of Parliament erased any distinction between evading impressment and desertion. ${ }^{14}$ The same act stipulated financial punishments, incarceration, transportation, and forced military service for those found to be aiding and abetting this "desertion". ${ }^{\text {Is }}$

I I. Tim Flannery (ed.), The Life and Adventures of John Nicol, Mariner (New York, I997), p. 26. Emphasis is my own.

I 2. "Vice Admiral Samuel Graves to Philip Stephens, Secretary of the British Admiralty", Preston, Boston, 20 February 1775, in William Bell Clark et al. (eds), Naval Documents of the American Revolution, I I vols to date (Washington DC, I964), I, p. 98.

I3. "Mr. Serjeant Foster's Argument concerning Pressing of Seamen, I743", The National Maritime Museum, Caird Library, Greenwich, UK [hereafter NMM], Hartwell papers (HAR)/s.

I4. NMM, Personal Papers of Sir Gilbert Elliot, Treasurer of the Navy, I722-1777, ELL/9.

Is. Ibid. 


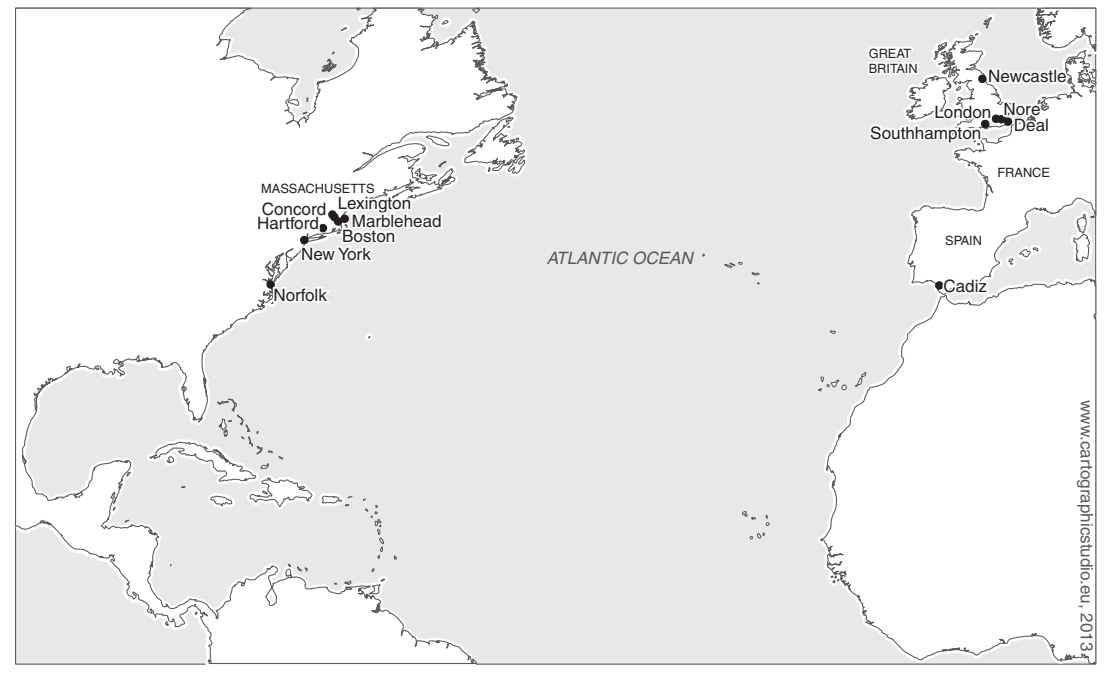

Figure I. Atlantic coastal communities, c.1775.

For those who actually "deserted", the removal of the distinction between impressment and desertion meant death. George II's 1757 royal proclamation made desertion a capital crime. ${ }^{16}$ Why, then, were maritime laborers willing to use violence to resist British naval impressment? Why would British subjects even consider murdering a British naval officer? Answers to these questions made for a revolutionary era.

In North American coastal communities, workers were engaged in a variety of radical actions during the 1760 s and 1770 s that helped bring about the American Revolution. Maritime laborers joined Sons of Liberty organizations; they threatened Stamp Tax collectors and customs agents with physical violence, and they destroyed private property. ${ }^{17} \mathrm{Tar}$, a nautical weatherproofing agent, became a subversive weapon in the hands of maritime mobs that tarred and feathered British officials. ${ }^{18}$ Maritime laborers in colonial ports converted ship masts into liberty poles to celebrate the repeal of offensive British legislation. The same workers then rioted whenever British soldiers stationed in North American cities tore down these liberty poles. In what has come to be known as the Battle of Golden Hill, thousands of mariners in New York City engaged in armed combat with British soldiers on I9 January I770 following the removal of

I6. NMM, "By the King, A Proclamation, For giving Encouragement to Seamen [...]", ELL/9. 17. See Benjamin L. Carp, Defiance of the Patriots: The Boston Tea Party and the Making of America (New Haven, CT, 2010); and Maier, From Resistance to Revolution.

I 8. Benjamin H. Irvin, "Tar, Feathers, and the Enemies of American Liberties, 1768-1776", The New England Quarterly, 76 (2003), pp. 197-238. 
the local liberty pole. ${ }^{19}$ And, to be sure, there was resistance to naval impressment such as the Pitt Packet affair. Collectively, workers' resistance in the streets generated a public discussion about the nature of British imperial authority. This resistance and discussion made policies such as the Stamp Act unworkable, and ultimately caused the British imperial machine to grind to a halt.

Certain preconditions made anti-impressment collective actions more likely to occur, the first of which was increased impressment itself. The British navy was most likely to press maritime laborers into military service during wartime. ${ }^{20}$ According to Rogers, impressment was statistically most likely to occur over the course of the first year of a war, when demand for labor was exceptionally high, naval wages were notoriously low, and volunteerism was pitifully insufficient. ${ }^{21}$ At the start of the Seven Years' War, for example, the number of men mustered into the British navy jumped more than threefold, from 9,797 in 1754 to 29,268 in $1755 .{ }^{22}$ Military mobilization increased press-gang activities and generated unusually high levels of resistance.

The state of the economy in and around a port also bore on the frequency with which workers resisted impressment. The fact that wages in the private sector increased during periods of conflict made maritime laborers especially motivated to resist being forced into military service at this time. Left to their own devices, maritime laborers could have secured unusually high wages. As a London newspaper writer explained in 1775 "The cruelty of issuing press warrants has been long and justly complained of. The English tars, brave as they are, have no objection to be paid." ${ }^{23}$ Impressment effectively cut workers' wages at a time when labor was scarce and pay high. During the eighteenth century, the primary focus of this essay, wartime wages on merchant vessels typically stood at on average 50-60 shillings per man, per month. At the same time, an able-bodied naval seaman earned 24 shillings per month. ${ }^{24}$ Workers still resisted impressment when wages were low and jobs were scarce in the private sector. During peacetime in 1770 outside London, for example, it was reported that a mariner shot a naval officer "dead on the Spot" after the officer and a press gang came after

19. Richard Ketchum, Divided Loyalties: How the American Revolution Came to New York (New York, 2002), pp. 224-236.

20. Historians of the Royal Navy agree on this point: N.A.M. Rodger, The Command of the Ocean: A Naval History of Britain, I649-I8Is (London, 2006), esp. pp. 395-396; Baugh, British Naval Administration in the Age of Walpole, esp. pp. 147-240; and Gradish, The Manning of the British Navy During the Seven Years' War, esp. pp. 54-86.

21. Rogers, Press Gang, p. 42.

22. Rodger, The Command of the Ocean, app. VI, p. 638.

23. "News from London", dated 2 I July 1775, Virginia Gazette, 5 October 1775.

24. Baugh, British Naval Administration in the Age of Walpole, p. 229. 
the sailor. ${ }^{25}$ Men never wanted to be coerced into naval service, in peacetime or wartime. Yet losing the ability to earn higher than normal wages in the private sector during wartime gave workers extra incentive to resist impressment.

The nature of a ship captain's authority, on a merchant vessel and on a warship, also impacted the likelihood that anti-impressment actions would occur. The captain of a merchant vessel may have abused his crew, making them unruly, and even openly hostile. The abusive captain could then offer up such mariners to nearby naval officers, who would press the men. In I775, at the start of the Revolutionary War, British General Thomas Gage wrote to Vice Admiral Samuel Graves to ask the naval commander to ban the impressment of seamen off the army's transport ships, which were hired merchant vessels bound for New York to get supplies for the army. The vice admiral denied this request. Graves explained that "We never impress the Transports people but in Cases of very bad behavior and at the Master's Request". ${ }^{26}$ In 1740 , "sturdy Fellows belonging to a [merchant] Ship near Southampton [England], having refused to go the Voyage without a Rise of Wages, left their Vessel. Upon which, the Master thereof gave Scent of them to a Press Gang, who, with the Assistance of some Constables, in short, seized them". ${ }^{27}$

A vindictive naval commander could also abuse his authority and press men out of spite or personal animosity. After the Committee of Safety in Marblehead, Massachusetts, confiscated some of Graves's personal effects that had been imported into the coastal community in violation of the Continental Congress's non-importation agreement, the British vice admiral stationed a warship outside Marblehead's harbor, "pressed several Men", and, according to a naval officer at the scene, Graves wanted "to burn their Town". ${ }^{28}$ In either civilian or military cases, the nature of the captain's authority and the ways in which he wielded power could increase the activity of the press gang, which would provide additional opportunity and incentive for resistance.

In addition to these preconditions, a combination of deep-seated beliefs and practical experiences prompted maritime laborers to resist British naval impressment around the Atlantic world. They drew on the ideals of

25. New York Gazette, 26 November 1770; Pennsylvania Gazette, 29 November 1770; Essex Gazette, I I-I 8 December 1770; Boston Post Boy, I7 December 1770; Connecticut Gazette, 2 I December 1770 .

26. "Vice Admiral Graves to General Thomas Gage", Boston, in June 1775, in Clark et al., Naval Documents of the American Revolution, I, p. 656.

27. Boston Evening Post, i4 April 1740.

28. "Diary of Lieutenant John Barker", entry dated Boston, 8 February 1775, in Clark et al., Naval Documents of the American Revolution, II, pp. 8I-82. 
the Levellers, a radical political group of the mid-seventeenth-century English Revolution that originally protested enclosure and the expropriation of labor. The expansion of the Royal Navy began under Charles $\mathrm{I}$, and the use of impressment to man the burgeoning fleet drew the Levellers' ire and contributed to the outbreak of civil war. Eventually, the Levellers promoted radical ideas such as popular sovereignty, the freedom of conscience, individual liberty, religious toleration, and equality before the law. ${ }^{29}$ The demand for individual liberty was especially subversive in a deferential, hierarchical, corporatist society such as seventeenth-century England. Individual rights threatened to subvert the top-down structure of society.

Throughout the I640s, the Levellers defended individual freedoms in their opposition to the government's use of impressment. This was a collective defense of individual rights. "The matter of impressing and constraining any of us to serve in the wars, is against our freedom", they wrote. There was "nothing more opposite to freedom", or no greater form of slavery, Levellers believed, than naval impressment. For this coercion violated "every man's Conscience", and it brought "hazards [to] his life" on a daily basis. ${ }^{30}$ Following a string of anti-impressment collective actions, the "Seamen belonging to the Ships of the Commonwealth of England" were made to explain the motives behind their riotous behavior to Oliver Cromwell in I654. The seamen, like their Leveller contemporaries, stated that they viewed the naval impressment that had continued under Cromwell's rule as a form of "thralldom and bondage". The maritime laborers did not believe they owed deference to state institutions, including the government and the military. Rather, they viewed themselves as "freemen of England", and they understood impressment as violating "the Principles of Freedom and Liberty" which were their natural rights. For such men, the state's abuse of these rights prompted their collective resistance. ${ }^{3 \mathrm{I}}$ As a group, they were willing to defend individual rights against thralldom.

Levellers such as Thomas Rainborough were outspoken in their denunciation of various forms of slavery. During the Putney Debates, Rainborough decried the impressment of soldiers and sailors as nothing less than a form of bondage. He equated the forcible appropriation and distribution of poorer English laborers to overseas colonies with African slavery. And he called for

29. For more on the Levellers, see Michael Mendle (ed.), The Putney Debates of I647: The Army, the Levellers, and the English State (London, 2001); and Hill, The World Turned Upside Down.

30. Don M. Wolfe (ed.), Leveller Manifestoes of the Puritan Revolution (New York, 1944), pp. 80, 95, 227, 287, 347, 405.

3. To his Highness the Lord Protector: the humble petition of the sea-men, belonging to the ships of the Commonwealth of England (London, 1654 ). 
the end of the enslavement of Africans. ${ }^{32}$ These arguments generated a language of freedom and helped build anti-slavery sentiment in England that reinforced and justified militant resistance to press gangs.

Although elites forcibly suppressed Rainborough and other Levellers, maritime conduits helped to spread Leveller logic beyond Albion's shores to the wider Atlantic world. Sailors on merchant vessels, privateers, and warships routinely carried news and information across the ocean and effectively established a systematic English Atlantic communication network. ${ }^{33}$ Colonists living around the Atlantic world were made aware of Leveller activities and the events of the Civil War. ${ }^{34}$ Captured Levellers were also transported to work and die on overseas plantations. ${ }^{35}$ The ideas that they shared were passed down from generation to generation.

Radical Leveller language was expressed in colonial American resistance to naval impressment as demonstrated in 1769 by the Pitt Packet affair. The court proceedings and the newspaper coverage that this sensational event generated offer an uncommon window into the radical motivations behind workers' resistance to impressment in colonial America just prior to the Revolution. ${ }^{36}$

Like the Levellers, Corbet and his mates collectively believed impressment into British naval service was a form of state-sponsored slavery, and that they were fighting for nothing less than their liberty from oppressive authority. James McGlocklin, a cook who worked with the Irish-American mariners, testified that Corbet and his mates responded to the press gang's command to come up on deck by stating "they were Freemen born free, and would not go aboard a Man of War". ${ }^{37}$ James Siley, a British marine, and a member of the press gang, and John Roney, the master mariner on the Pitt Packet, both testified they heard Corbet and his mates "say they wanted nothing but their Liberty". ${ }^{8}$ Peter Bowen and William Peacock, midshipmen on the British warship, testified

32. Linebaugh and Rediker, The Many-Headed Hydra, ch. 4, esp. pp. Io9-I I I.

33. Ian K. Steele, The English Atlantic, 1675-1740: An Exploration of Communication and Community (London, 1986). For more on the particular role sailors played in this communication network, see Julius S. Scott, "Afro-American Sailors and the International Communication Network: The Case of Newport Bowers", in Colin Howell and Richard Twomey (eds), Jack Tar in History: Essays in the History of Maritime Life and Labour (Fredericton, NB, I99I), pp. 37-52.

34. See Carla Gardina Pestana, The English Atlantic in an Age of Revolution, 1640-I66I (Cambridge, MA, 2007).

35. Linebaugh and Rediker, The Many-Headed Hydra, ch. 4 .

36. For the proceedings of the Vice Admiralty court that tried the Marblehead mariners, see Wroth and Zobel, Legal Papers of John Adams, II, pp. 275-335. For newspaper coverage of this event, see Dickerson, Boston Under Military Rule, pp. 94-95, 104-105.

37. Wroth and Zobel, Legal Papers of John Adams, II, p. 320.

38. Ibid., pp. 309, 319 . 
Corbet and his mates "said they were resolved to die, sooner than be pressed on Board a Man of War". ${ }^{39}$ It was reported in a New York newspaper that:

This Outrage of the Press Gang, so far from intimidating, increased the Resolution of the Men to die, rather than surrender themselves to such a lawless Banditti; and indeed their whole Conduct seemed to manifest an Abhorrence of being forced on board a Man of War, and that they preferred death to such a Life as they deemed Slavery. ${ }^{\circ}$

Patrick Henry was not the only colonist to maintain a liberty-or-death ethos. Thomas Hutchinson, Royal Governor of Massachusetts, wrote that "The seamen had shut themselves up in the fore peak, and had furnished themselves with harpoons, and other weapons [...] and swore they would die before they would be taken, and that they preferred death to slavery." ${ }^{\mathrm{r}}$

Freedom and liberty were deeply ingrained in eighteenth-century American seafarers' lexicon, no less than in Levellers' hearts. A Massachusetts newspaper reported that at the start of 1769 mariners in Boston referred to British warships as "wooden prisons". ${ }^{2}$ Christopher Prince, a Massachusetts mariner pressed into the British navy at the start of the Revolutionary War similarly referred to life "on board of a British [naval] vessel and under the command of British subjects" as "thralldom". ${ }^{43}$ For maritime laborers, resisting impressment was a public, radical commentary on the legitimacy of British authority that was deeply rooted in seventeenth-century English political ideas. ${ }^{44}$ Militant anti-impressment collective action was not simply a localized effort to fend off a press gang. Just as the Levellers viewed impressment as an infringement of natural rights and an indication of the abuse of state power during the English Revolution, colonial American maritime laborers equated impressment with state-sponsored slavery prior to the American Revolution. ${ }^{45}$

39. Ibid., pp. 294, 300 .

40. New York Journal, 22 June i769.

41. Thomas Hutchinson, The History of the Province of Massachusetts Bay, From 1749 To 1774, Comprising A Detailed Narrative of the Origin and Early Stages of the American Revolution (London, I 828), p. 23 I.

42. Essex Gazette, 7 March 1769.

43. Michael J. Crawford (ed.), The Autobiography of A Yankee Mariner: Christopher Prince and the American Revolution (Washington DC, 2002), p. 59.

44. According to Paul Gilje, it was only after the American Revolution that many sailors internalized political ideology and became politically conscious. Prior to the Revolution, sailors lived for the moment and their notions of liberty reflected very practical daily concerns associated with shore leave. See Paul A. Gilje, Liberty on the Waterfront: American Maritime Culture in the Age of Revolution (Philadelphia, PA, 2004).

45. For more on the ways in which radical ideas connected seventeenth-century English dissenters and eighteenth-century American revolutionaries, see Margaret C. Jacob and James R. Jacob (eds), The Origins of Anglo-American Radicalism (Boston, MA, 1984); and Staughton Lynd, Intellectual Origins of American Radicalism (New York, I968). 
Popular perceptions of press gangs were directly related to the ways in which workers conceived of the nature of government authority. Benjamin Franklin, a prolific writer, one of the most democratic Founding Fathers, and a man who lived in port cities most of his life, amplified the voices of maritime laborers on this score. Echoing the Levellers, Franklin wrote that impressment took away people's natural freedom. He emphasized that impressment was especially exploitative, as it occasioned "the Loss of Liberty and Hazard of Life". By using force against its own people, the British government had become corrupt and tyrannical. It was turning free wage laborers into slaves. In no uncertain terms, Franklin linked British naval impressment and the legitimacy of the British state: "If impressing Seamen is of Right by Common Law, in Britain, Slavery is then of Right by Common Law". Giving voice to the concerns of many, Franklin hammered home the old Leveller saw that there was "no Slavery worse than that Sailors are subjected to", because of the constant dangers of death. For Franklin, and for the thousands of maritime laborers whose shoulders he stood on to shout, any government that defended and utilized impressment "doth not secure Liberty but destroys it" ${ }^{46}$ Repeated attempts to press colonial maritime laborers helped to convince colonists in and out of doors that their government had lost its legitimacy.

Impressment also raised workers' political consciousness beyond the shores of North America, helping maritime laborers associate British authority with tyranny. In England, John Stradley was pressed into naval service near London at the end of the American Revolution. Of this impressment, Stradley wrote, "I was stolen away [...] and locked down in the hold with a sentinel over me with a drawn sword as if I had been a thief or a Murderer". Upon finishing his naval service, Stradley wrote, "I got Clear of that miserable situation of a seafaring life [...]. I again rejoiced in my liberty and thought it a great happiness to be free from [...] the Constraint of Tyrannical Officers". 47 John Nicol, who was pressed into the British navy during the French Revolutionary Wars, referred to impressment as "a bondage that had been imposed upon me against my will" ${ }^{8}$ On both sides of the Atlantic, workers were concerned

46. Franklin's Remarks on Judge Foster's Argument in Favor of the Right of Impressing Seamen, $178 \mathrm{I}$, in The Papers of Benjamin Franklin, at http://www.franklinpapers.org/franklin/ framedVolumes.jsp, last accessed 23 April 2013. For more on Franklin's democratic politics, see Gary B. Nash, "Philadelphia's Radical Caucus that Propelled Pennsylvania to Independence and Democracy", in Alfred F. Young, Gary B. Nash, and Ray Raphael (eds), Revolutionary Founders: Rebels, Radicals, and Reformers in the Making of the Nation (New York, 20I I), pp. $67-86$.

47. NMM, Copies of Volumes and Documents - Transcripts (TRN)/38.

48. Flannery, The Life and Adventures of John Nicol, pp. 162-163. 
about liberty, and these concerns had a direct bearing on popular political perceptions of British authority and resistance to impressment.

Practical experience at sea informed collective resistance as well as deepseated popular beliefs about natural rights and good government. Naval service was a life-or-death proposition that brought abstract political concepts home to poorer, uneducated laborers. Rigid forms of discipline, low pay, work-related hazards, and lengthy periods away from home all made warships into schools of hard knocks in which workers became politicized. In I654, maritime laborers explained to Cromwell that their anti-impressment riots had been partially caused by the "great hardship" associated with naval service. This included death, wounds, and sickness: "Sea-men having sacrificed themselves [i.e. died in the line of duty]; and some of our limbs are mangled, and blood spilt $[\ldots]$ besides great diseases and distempers, sometimes occasioned through bad Victual". ${ }^{49}$ These rioters were men with prior naval experience who resisted in order not to be forced back into naval service.

Feeding naval seamen proper provisions remained habitually problematic for the British navy throughout the early modern era. ${ }^{50}$ Bad food continuously generated bad blood between naval seamen and the navy. The navy also gained a widespread reputation for brutal forms of discipline. Physical forms of abuse that included floggings were not uncommon. There was also psychological abuse associated with confinement. ${ }^{\text {I }}$ Maritime laborers around the Atlantic world were also well aware that the British navy did not pay well. Massachusetts royal governor William Shirley explained this fact to Commodore Augustus Keppel in 1755. Shirley informed Keppel that it would be very difficult to man the fleet in Boston "for the King's usual Pay".52 That same year, Captain Housman Broadly informed Vice Admiral Edward Boscawen "there will be no getting Seamen at New York or Boston to come up early in the Spring upon the Wages allowed in the Navy".53

49. To his Highness the Lord Protector.

50. One of many examples that could be provided on this score comes from TNA ADM 5I/7I/ 2, Captain's Logs for the Assistance, Captain Richard Edwards, between 22 May 1753 and 29 March 1754. Captain Edwards recorded in his logbook: 29 July the food was surveyed and "Condemned as not fit for men to Eat, nor to be Kept on board, being a nuisance to the Ship's Company". The rotten food was "thrown overboard into the Sea". For an overview of the British navy's logistical challenges, see David Syrett, Shipping and Military Power in the Seven Years War: The Sails of Victory (Exeter, 2008).

5. John Nicol noted various forms of harsh discipline during his eighteenth-century service in the Royal Navy; Flannery, The Life and Adventures of John Nicol.

52. TNA ADM I/480, Letters from Admirals on the North America station from 1 $745-1777$, Letter from Governor William Shirley to Commodore Augustus Keppel, Boston, 20 May 1755 . 53. TNA ADM I/480, Letters from Admirals on the North America station from 1745-1 777 : Letter from Captain Housman Broadly to Edward Boscawen, Vice Admiral of the Blue, Oswego, is February 1755. According to Daniel A. Baugh, an authority on British naval administration, the navy did not increase wages for seamen at all between I 686 and the start of the American Revolutionary War. These meager earnings appeared worse during wartime, when 
This reputation preceded press gangs into ports, and it contributed to workers' willingness to resist impressment. Maritime laborers' resentment toward impressment thus represented the confluence of radical ideas and lived experiences. This resentment contributed to militant collective resistance to naval impressment.

There were, of course, peaceful, law-abiding ways of protesting naval impressment that did not pose a threat to the status quo in eighteenthcentury colonial America. Even in the midst of a 1768 anti-impressment riot in Boston, local elites calmly held a town meeting and pursued formal avenues of protest. Town Selectmen, elected local officials, resolved to send a deferential letter to Massachusetts' Royal Governor, Francis Bernard, requesting that the governor use his authority to have the naval officer in charge of the recent impressment removed from the area. Naval impressment had been illegal in North America since a I 708 parliamentary ban on the practice. The town leaders then published Bernard's negative response in the local newspaper. ${ }^{54}$ Elites held another town meeting and further resolved to send "instructions" to their representatives in the Massachusetts legislature. ${ }^{5}$ The Selectmen even resolved to forward their protests to their lobbyist in Parliament, only to wait patiently for a response. ${ }^{56}$ The goal of all these protests was not to upset the balance of the standing social or political order, but simply to convey dissatisfaction to the proper authorities through formal channels in the hope that superiors would be the ones to effect change.

There were also widespread, conservative sorts of crowd actions that American colonists could have employed in reaction to impressment. Humiliation by charivaris and rough music, for example, were common eighteenth-century communal methods of defending moral economies. ${ }^{57}$ Theoretically, colonial American communities could have publicly shamed naval officers into submission. These traditional shaming rituals seem to have worked best, however, when they targeted community members, which excluded British naval officers in colonial America. By and large, colonial American maritime laborers did not adopt elite or popular conservative means of protesting naval impressment on the eve of

merchants and privateers doubled or tripled standard pay rates to attract workers. See Baugh, British Naval Administration in the Age of Walpole, p. 229.

54. "News from Boston dated June 20, I768", Virginia Gazette, I4 July I 768.

55. Ibid.

56. Ibid.

57. Peter Burke, Popular Culture in Early Modern Europe (New York, 1978); Natalie Zemon Davis, Society and Culture in Early Modern France (Palo Alto, CA, 1975); Dirk Hoerder, Crowd Action in Revolutionary Massachusetts, I765-I780 (New York, 1977); George Rudé, The Crowd in History: A Study of Popular Disturbances in France and England, 1730-1848 (New York, 1964); and E.P. Thompson, Customs in Common: Studies in Traditional Popular Culture (New York, I99I). 
the American Revolution. They engaged in direct action to effect change themselves. They did not petition politely for contemplative consideration of a list of grievances, and they did not wait patiently for a response from superiors. They angrily demanded immediate change, and they were willing to use violence to bring it about.

Collective anti-impressment actions had common phases, just like shipboard rebellions. First, a core of a few individuals agreed to fight against a press gang that was known to be operating in a port. We know this because of the bounties placed on ringleaders, and the financial rewards that were offered for information leading to their arrest or capture. In the aftermath of the Knowles anti-impressment riot in Boston in I747, William Shirley, the Massachusetts Royal Governor, wrote to the Admiralty to inform them that he had proposed "the immediate issuing of a Proclamation for dispersing the Mob, and Discovering and Apprehending the Ringleaders and others concerned in it". Shirley's proclamation included a "Reward to be given" for information leading to the ringleaders' arrest. ${ }^{58}$ Following an antiimpressment riot in Deal, England in 1755 , the Admiralty publicly offered "a Reward of Two Hundred Pounds for the discovering, apprehending, and prosecuting of all, or any three or more of the Persons who were principally guilty of the several Offenses aforesaid".59

The principals then formed a collective, which could range in size from a small group to several hundred maritime laborers. In June 1765 a New York City mob burned the tender of HMS Maidstone on the city commons after press gangs had swept through the colonial port. ${ }^{60}$ It was reported that:

Tuesday Evening last, about Nine o'Clock, his Majesty's Ship the Maidstone's Boat was taken from one of the Wharves, by a Mob consisting chiefly of Sailors, Boys and Negroes, to the Number of above Five Hundred, haul'd up through Queen-Street to the Common, at the upper End of the Town, where they burnt her, in the Circle of the exasperated Tumult, which I believe every sensible Man in Town much regrets, and am persuaded was out of the Power of the Authority to prevent her Fate, as it was but a few Minutes from the Time of their taking her to her being in Flames. ${ }^{61}$

By comparison, there were only four mariners involved in the Pitt Packet resistance, in which Corbet was clearly the ringleader. ${ }^{62}$ All such maritime collectives prepared for self-defense.

58. TNA ADM I/3818/289.

59. "Letter from the Admiralty Office, dated March 24, 1755", London Gazette, 25 March 1755 (emphasis my own).

60. A "tender" was a small vessel attached to a large warship, used in impressment raids.

61. Newport Mercury, io June i765.

62. As a member of the Marine Committee, John Adams recommended Michael Corbet for a captain's commission in the continental navy because of the leading role the mariner played in 
Militant maritime laborers were willing to use violence to protect their freedom. They often destroyed the navy's property. Commodore Charles Knowles authorized press gangs to operate in Boston in 1747. Forty men were taken off the streets by force and chained below decks in tenders that made their way to warships as the well-documented Knowles Riot broke out in Boston. In this collective action, maritime laborers rioted for three days. A mob captured British naval officers, held them hostage, and generally seized control of the colonial port city. Colonial mariners even took and set fire to one of the tenders that belonged to the navy. ${ }^{63}$ Similarly, Lieutenant Thomas Laugharne of the sloop Chaleur pressed five men from various vessels outside New York City in 1764. New Yorkers formed a mob and burned the Chaleur's tender in front of the port's meeting hall. ${ }^{64}$ One year later, a New York City mob burned the tender belonging to HMS Maidstone on the commons after press gangs had swept through the port. ${ }^{65}$

Then, in the summer of 1768 , American colonists in Boston, Massachusetts, rioted following three consecutive instances of impressment. Repeated impressment had "raised the resentment of the populace", and united colonists in opposition to British imperial authority. The "people in town" were "in great agitation". Notices were "posted up in diverse parts of the town requesting the Sons of Liberty to meet at Liberty Hall". Sons of Liberty flags "were flying on [the] Liberty Tree" in Boston. ${ }^{66} \mathrm{~A}$ mob of some 2,000 angry people, many of them sailors, dragged one of the navy's tenders from the waterfront to Boston's liberty tree. The mob conducted a mock Vice Admiralty Court and condemned the navy's property, then carried the boat to the commons and set it ablaze. ${ }^{67}$ In each case, colonists collectively confiscated and destroyed British naval property - the hated tender. These vessels, like Charon's boat that crossed the river Styx in Greek mythology, were symbols of the separation of life and death. Burning these symbols, especially in front of a liberty tree, represented a powerful plebian celebration of life and freedom. Setting fire to a tender was akin to burning a larger naval warship in effigy, on a miniature scale.

the Pitt Packet affair; Phillip Chadwick Foster Smith (ed.), The Journals of Ashley Bowen (I728-1813) of Marblehead, 2 vols (Portland, ME, I973), I, pp. 208-209, fn 4.

63. Letter from Governor Shirley to the Admiralty, Boston, I December I747, ADM I/38 I 8/ 285 . For more on the riot, see Denver A. Brunsman, "The Knowles Atlantic Impressment Riots of the I740s", Early American Studies, 5 (2007), pp. 324-366; William Pencak and John Lax, "The Knowles Riot and the Crisis of the 1740 s in Massachusetts", Perspectives in American History, Iо (1976), pp. 163-214.

64. Lemisch, Jack Tar vs John Bull, p. 27.

65. Ibid.

66. "News from Boston", dated I6 June I768, Virginia Gazette, I4 July I768; Boston Post Boy, 20 June 1768; New York Gazette, 27 June 1768; Pennsylvania Gazette, 30 June 1768.

67. "News from Boston", dated 23 June I768, Virginia Gazette, 2 I July 1768. For more on this event, see Hoerder, Crowd Action in Revolutionary Massachusetts, pp. 164-184. 
Such militant behavior set these collective actions apart from more polite, refined forms of political protest that involved town meetings, resolutions, memorials listing grievances, formal avenues of power, and waiting. Moreover, crimes against property were especially prosecuted in Anglo-American parts of the world. As Peter Linebaugh has demonstrated, the Crown and Parliament became increasingly active in inventing capital crimes and prosecuting offenders to preserve property rights over the course of the early modern era. ${ }^{68}$ Riot acts were also established to preserve domestic tranquility and protect property from destruction. Burning naval property violated this sense of propriety and these laws, and it did so in a very public and overtly political manner. Destroying the navy's property on the commons, or before government-owned town halls, was highly subversive in a deferential hierarchical imperial world.

Maritime collectives also arrested press gangs. A mob of maritime laborers in Norfolk, Virginia, forcibly resisted being compelled to serve in the British navy in 1767 . The armed sloop Hornet sailed into Norfolk on 5 September, and Captain Jeremiah Morgan landed with a press gang of around thirty men. Morgan had received press warrants authorized by King George III legitimizing naval impressment. After imbibing "a little Dutch courage" at a local tavern, Captain Morgan and his armed press gang "proceeded to that part of the town resorted to by seamen". The press gang attempted to strong-arm American colonists into joining the navy. The gang had captured several men when the local watch raised an alarm, and a mob of around roo port denizens turned out and forcefully fought off Morgan and his crew. The press gang retreated to the Hornet in the face of this resistance, but not before colonists seized 30 of the naval seamen and placed them under arrest in the port's jail for the weekend. ${ }^{69}$ It is likely that the maritime laborers involved in this affair were members of the Norfolk Sons of Liberty.

American maritime laborers were also willing to use intimidation to defy what was popularly perceived as a corrupt British government. On 2 February 1775, HMS Lively sat at the harbor mouth outside Marblehead, Massachusetts. Vice Admiral Samuel Graves, commander of the British fleet on the North American station, had ordered "the Lively at Marblehead, to raise men for the Squadron", and Graves "directed Captain [Thomas] Bishop of the Lively to press thirty Seamen". The Vice Admiral acknowledged in an official communication that Marblehead was "a place extremely violent in supporting and carrying into execution the Resolutions and Directions of the Continental Congress respecting

68. Peter Linebaugh, The London Hanged: Crime and Civil Society in the Eighteenth Century (London, 2003).

69. "News from Norfolk", dated s September 1767, Virginia Gazette, I October 1767. 
the Non-importation Agreement". ${ }^{70}$ By this, Graves meant that Marbleheaders had gone so far as to impound some of his personal effects that had been imported into the coastal community. Captain Bishop then stopped privately owned commercial vessels entering Marblehead's harbor, and he ordered his Lieutenant, William Lechmere, and several of the Lively's crew to press maritime laborers into naval service.

Lechmere faced stiff resistance. According to HMS Lively's logbook, which Captain Bishop maintained, “At 2 a.m. manned \& armed the Pinnace and Cutter sent to Marblehead to Impress men at 9 ye Boats retd with Io Men" ${ }^{71}$ Ashley Bowen, a Marblehead resident who had worked in the cod fisheries and on locally owned merchant vessels before becoming a sailmaker, recorded in his diary that on 2 February 1775 the British man of war Lively "pressed ten men out of the vessels in our harbor". But, Bowen quickly noted, "Our people got 6 of them back again". ${ }^{72}$ The "people" who attempted to rescue the pressed mariners were most likely maritime laborers who worked in the port's commercial fishing industry. An observer described the activity involved in the return of one of these six detainees:

The Admiral issued press-warrants at Marblehead [...]. At first the people of Marblehead had determined on rescuing any pressed men; accordingly, after Mr. Lechmere, Lieut. of the Lively, had pressed two hands from on board a vessel coming in, on his return he was surrounded by eight or ten whale boats manned and armed; he called to them at their peril to keep off, which they did at a distance of two boats' lengths; they asked him if he had pressed any men out of the vessel he had boarded, which he answered in the affirmative; they bid him deliver them up without making any resistance; on his refusal, they pointed their pieces [i.e. weapons, most likely fowling pieces] into his boat, and Mr. L[echmere] ordered his men to do the same; one of the impressed men took this opportunity and leaped overboard; Mr. Lechmere snapped his piece at the man, which miss fired, and he was taken up by the whale boats; the other man was immediately secured, and without further opposition carried on board the Lively. ${ }^{73}$

The other five Marblehead mariners were probably rescued through similar acts of intimidation.

70. "Vice Admiral Samuel Graves to Philip Stephens, Secretary of the British Admiralty", HMS Preston, Boston, Massachusetts, 20 February 1775, in Clark et al., Naval Documents of the American Revolution, I, p. 98. For more on the 1774 Continental Association that the Continental Congress established and that local committees of safety and inspection enforced, see T.H. Breen, American Insurgents, American Patriots: The Revolution of the People (New York, 20I0), especially ch. 6.

71. Smith, The Journals of Ashley Bowen, II, p. 427.

72. Ibid. For more on Bowen, see Ashley Bowen, The Autobiography of Ashley Bowen (I728-I8I3), Daniel Vickers (ed.) (New York, 2006).

73. "A Private Letter from a Gentleman at Boston, Dated Feb. I9, I775", Morning Chronicle and London Advertiser, 8 April 1775, in Clark et al., Naval Documents of the American Revolution, I, pp. 93-94. 
The resistance of the Marblehead mariners made regional headlines. Newspapers in Boston, Massachusetts, and Hartford, Connecticut, reported that Graves had "arbitrarily treated" colonists in a port "mostly dependent on trade and navigation". Two months before more famous events at Lexington and Concord, the newspapers maintained that this affair "must convince the American colonies, that had they not nobly resolved to maintain and defend their rights and liberties, the most insignificant officers of the crown would have been authorized and encouraged to insult them". The Marblehead mariners were held up to the public as ideal patriots "determined to defend themselves against these unjustifiable proceedings" ${ }^{74}$

Colonial American maritime laborers were even willing to kill to defend their individual freedoms. The crew of the American privateer Sampson fired a "volley of musketry" against a press gang from HMS Winchester in August I760 near New York City, killing four British seamen. ${ }^{75}$ In the case of the 1769 Pitt Packet affair discussed above, the four Irish-American maritime laborers banded together and fought against the press gang until Corbet grabbed a harpoon, launched the weapon, and killed Panton, the naval officer. John Adams defended the mariners and got them acquitted on the basis of justifiable homicide in self-defense. Adams believed that British naval impressment raids were more powerful in raising Americans' political consciousness regarding the tyranny of their government than the Boston Massacre, in which he defended the British soldiers. In Adams's words, "Panton and Corbet ought not to have been forgotten". The Founding Father added, "Preston and his soldiers ought to have been forgotten sooner". ${ }^{76}$

Impressment also contributed to various mid-to-late eighteenthcentury mutinies. Indeed, resistance to impressment might be considered pre-emptive mutiny. Coerced military service enraged maritime laborers to the point that they were willing to violently overthrow the command of naval vessels at sea. In addition to the mutiny that took place near the Nore mentioned above, there were four separate occasions in which maritime laborers who had been captured by the British navy off the coast of Great Britain and confined below deck on tenders during transport to waiting warships rose up and violently seized control of the naval transport vessels. ${ }^{77}$ On two other occasions, crews of privateers near

74. Massachusetts Spy, I6 February 1775; Connecticut Courant, 20 February 1775.

75. Lemisch, Jack Tar vs John Bull, pp. I3-14.

76. Charles Francis Adams, The Works of John Adams, Second President of the United States, X, (Boston, MA, I 856), p. 2 I0. Captain Thomas Preston was in charge of the British soldiers who fired upon the mob in the Boston Massacre.

77. "Extract of a Letter from Portsmouth [England]", dated 26 May 1755, Virginia Gazette, 5 September 1755; TNA ADM r/924, E. Boscawen, 21 February 1757; TNA ADM i/920, enclosed letter to E. Hawke, 3 June 1755; and (1771) TNA ADM 106/1 197/239. 
London mutinied upon learning that their captains were going to allow press gangs to board their vessels. ${ }^{78}$

Such militant behavior struck terror into the hearts of elites, who feared a world turned upside down. William Douglass, a Boston physician, witnessed the Knowles anti-impressment riot and expressed his concern to the public that "this Tumult might have increased to a general Insurrection". He warned his readers that allowing the masses to overturn the social order, if only for a few days, posed the serious risk of mob rule or anarchy. ${ }^{79}$ In New York City, a local elite writing under the pseudonym "Anti-Licentiousness" responded to the anti-impressment activities of the Sons of Liberty in that port city in 1775 by warning the public,

$[\ldots]$ let us not establish the sway of a mob [...]. Many fellow-citizens have been deluded by the cry of liberty, which has been held up to them as the reason for these violences $[\ldots]$ so daring a violation of the good order and police of the City, so flagitious an insult on Magistracy, and contempt of the laws, ought not to be passed over with impunity; for let us remember, that the restraints of the law are the security of liberty. ${ }^{80}$

The fear sailors prompted in elites makes clear the subversive nature of their actions. Just as ship captains feared mutiny and the loss of their vessels, those with social standing feared insurrections that threatened their place in the standing order of things.

Maritime radicalism also inspired revolution. In I776, Thomas Jefferson listed naval impressment as one of the foremost grievances Americans had with the British government in the Declaration of Independence. The Founding Father wrote that the British government "has constrained our fellow Citizens". These citizens had been "taken Captive on the high Seas". Like the mariners at Marblehead, Massachusetts, they were forced to serve in the British navy at the start of the Revolutionary War in 1775, and they were made "to bear Arms against their Country, to become the executioners of their friends and Brethren, or to fall themselves by their Hands" ${ }^{8 \mathrm{I}}$ Impressment had become a casus belli. Thomas Paine, the famous revolutionary firebrand, wrote in his widely read Common Sense that "the present mode of impressing men" represented a powerful, intuitive justification for revolution. ${ }^{82}$

In sum, maritime laborers were militantly willing to defend freedom against tyranny, the central struggle of what would become the age of

78. TNA, Records created and inherited by the Treasury Board, I/392/I.

79. "News from Boston", dated I7 November 1747, New York Gazette, I I January I 748.

80. "Letter to Mr. Rivington", dated New York, I9 April I775, in Peter Force (ed.), American Archives, Series 4, 6 vols (Washington DC, I837-I853), II, p. 349.

8r. "The Declaration of Independence", at http://www.loc.gov/rr/program/bib/ourdocs/ DeclarInd.html, last accessed s May 20 I 2.

82. Thomas Paine, The Complete Writings of Thomas Paine, Philip S. Foner (ed.), 2 vols (New York, I945), I, p. I I. 
revolution. The motivations behind this militancy involved radical ideas and practical experience directly related to life at sea. Workers were willing to kill, mutiny, intimidate, and destroy property to achieve their goals. Many of the struggles against impressment were victories. Sailors liberated their "Brother Tars"; they repelled and in some cases jailed press gangs, demonstrating for all to see that freedom could, and should, be won and defended. By this process anti-impressment collective actions had a disproportionate influence on the larger movement toward revolution in the American colonies and beyond. Workers' militancy gave rise to the Declaration of Independence, not vice versa. Mariners thus helped to bring about the American Revolution and to inaugurate the world-shaking revolutionary era. 